\title{
Education as a Factor of Intercultural Communication
}

Grozdanka Gojkov ${ }^{1}$

$\approx$ The paper considers alternative constructivism as a possibility of theoretical starting point regarding education as a factor of intercultural communication. The introductory part of the paper deals with Kelly's personal construct theory permeating the arguments in favour of the theoretical research thesis referring to the issue of the extent the pluralism of European culture space interferes with national culture through education. Furthermore, the paper considers the way pedagogy has been searching for more comprehensive self-observation, self-reflection and self-determination on its way to self-change in order to ensure freedom of personal action according to contemporary philosophical discussions. The importance of education as a factor of intercultural communication has been supported by the outcomes of an explorative empirical research, which is an element bonding all the reflections in the text. Finally, the key competences for intercultural communication have been stated in the paper.

Keywords: Education, Intercultural communication, Pedagogy

\section{Introduction}

Constructivist approaches within contemporary theoretical pluralism have brought about new approaches to the explication and understanding of processes and phenomena in both the individual and social functioning of the individual. The changed perception of man, the different approach to the development and possibility to educate human potential, has strongly influenced the field of education, opening new perspectives for reflection. The concepts of development and education of an individual have in this sense taken increasingly more space; in accordance with the acceptance of the »challenge model« the

1 Preschool Teacher Training College »Mihailo Palov«, Vrsac \& Teacher Training Faculty,

Belgrade University

ggojkov@hemo.net 
concept of competence has been created, estimated by contemporary authors as a notion that in the best way sublimes the model of human functioning, based on developmental theoretical directions. The adoption of the concept is based on its insistence on the link between personal development and the features and meanings of social discourse, and it is grounded in a developmental-humanistic, mutual and responsible relation individual-community. Education has a special role to play in the concept, having in mind the encouragement of the development of human potential to acquire competences as the general ability of an individual. Competence is understood in contemporary pedagogical approaches as a complex of potentials, the developmental capacity of an individual who can be educated and leads to the successful achievement of one's own aims, needs and roles in various fields of social and professional life, as well as to interpersonal and satisfactory communication with others. For pedagogy and education the latter is especially important since it is considered that European integration will have stronger support if full attention is paid to the acquisition of competences whose key attributes are considered to be the following: the power of analytic thinking, team work skills, independence, professionalism followed by self-initiative, as well as intercultural communication competence.

The literature offers numerous concepts of competences; what has, among others, frequently been stated is Richter's understanding of the concept of competence (Gojkov \& Stojanović, 2009), taking into consideration a person and influencing his/her self-reflection and self-determination. In this sense, the attitude towards a learner in education has changed significantly. A learner is no longer in a position to apply the learned, the specific and what is adaptable to a situation; he/she is rather in a position:

- to change what he/she has learned according to his/her own needs,

- to integrate new alternative ways of action into the system,

- to choose between more alternatives, in order to behave properly,

- to connect new learnt abilities with other abilities,

- to broaden his/her own repertoire of behaviour and displace it from that which is in itself grounded synergy to others, i.e., to expand the alternatives of his/her behaviour by linking previous abilities and those newly acquired.

\section{Education as a Factor of Intercultural Communication}

We will now turn to education as a factor that could - through the promotion of a shared civil culture grounded on the human, through the encouragement of the mutual respect of the cultures of others, as well as through the 
acknowledgement of the collective rights of all nations as equally valuable make a significant step towards the ability of an individual to better understand all of the increasing complexity and changes occurring around him/her. This could further make a contribution to the struggle against the feeling of insecurity arising out of everything that has been mentioned. The first step is the acquisition of adequate knowledge, followed by its articulation in the temporal perspective, along with a constant critical approach. Consequently, education is a reference point that can help an individual to become a citizen of a changing Europe, bearing in mind that the purpose of education is not for an individual to develop features making him/her similar to others, but rather to provide him/her with abilities to valorise his/her existence and achieve the expression of his/her own features. Another question arises here regarding the extent to which the processes of mobility of people and ideas, the appearance of new information and communication technologies, have created new circumstances »making it difficult» for an individual »to grow up and mature», bringing about an identity crisis with the consequence that people are now inclined to more readily emphasise the identity of a community grounded on ethnic values, nation, religion and territory.

What is today pointed out in common resolutions, conclusions and other documents issued by the bodies of the European Union is that education has a more emphasised critical responsibility to transfer values to young people and help them make not only wise but humane and moral decisions. As a consequence, young people have to be provided with possibilities to build a system of values appropriate to these aims, characterised by altruism, empathy and human understanding, to develop self-respect and an ability to love, to be trained to plan and anticipate the consequences of their own decisions and actions, implying tolerance, listening skills, problem solving skills, an ability to perceive the sense in everything we do, in what is going on around us. Also worth mentioning are the skills of taking responsibility and initiative, as well as many other characteristics implied by team work. On a practical level this means that young people can be involved in team work, demanding creativity and individual contributions to qualitative results (often even in ad hoc teams). To what extent are these qualities developed in individuals and how much attention is paid to them? Can individuals with an expressed inclination towards the development of knowledge with the promise of practical use neglect their own needs and turn to the needs and interests of others? To what extent is moral competence inevitably implied by teaching content nurtured and promoted? How much attention is paid to mastering successful social integration? How much do we care for the competences permeating free decision making on when and how we should take mature steps? 
We should now for a moment focus on the findings of an explorative empirical research project ${ }^{2}$ attempting to consider the extent to which purpose, a life ideal, is manifested as an expression of giftedness, a mature manifestation of intrapersonal intelligence (an inner control system, a compass) and orientation according to which a gifted individual guides him/herself, self-regulates his/her engagement in culturally valuable activities. Furthermore, a relation has been considered between purpose assessment and the meaning of life as one of the values in the structure of values and achievements of the gifted, with the assumption that the gifted have more expressed orientation in the sense of the purpose of their engagement, as well as a stronger self-understanding, a more consistent self-image, as a critical ability leading to both greater academic achievements and the overall contribution to the society in which they live. The research was undertaken on a sample of 96 MENSA members in Vojvodina, and the basic finding refers to the following.

As an ideal, purpose is conceptualised in the case of the gifted as a manifestation, a regulator (a guide) and an inner moral compass significantly correlating with achievements, as well as with an inclination to make a greater contribution to their social setting and a self-orientation towards positive aspirations. Why do I consider this worth mentioning here? The relevant literature considers the purpose of life to be a moral value, i.e., a special giftedness in intrapersonal intelligence. In other words, purpose is an inner moral compass, a stable and general intention to do something considered essential for the personality, having consequences that go beyond the personal context (Damon et al., 2003). Some authors have also emphasised that purpose is a question of getting to know oneself as well as one's own place in the world, which is very important as a regulator, i.e., it facilitates self-regulation of the way a person is engaged in culturally valuable activities (Zimmerman, 2008), emphasising that the value of this feature of intellectual maturity is above the personality itself (Gestottir \& Lerner, 2007). This is relevant to the research undertaken, bearing in mind that the assumption has established a connection between two sides of giftedness, i.e., the moral and the intellectual, which each in its own way has been of great interest and has found a place in the considerations of the interactivity of these processes in the gifted. The starting point of the research was the definition of purpose, whose main characteristics imply that purpose

2 See: Grozdanka Gojkov and Aleksandar Stojanović (2010), Svrha u strukturi vrednosti darovitih u Srbiji kao kritička sposobnost i moralni vodič [Purpose in Value Structure of the Gifted as Critical Ability and Inner Moral Guide], Socijalne in čuvstvene potrebe nadarjenih in talentiranih, Zbornik II. mednarodna znanstvena konferenca, MIB, 2010. Bled. 
is an inner compass involving engagement in activities influencing other people, as well as self-awareness and intention, a readiness to take further steps in this direction. It seems important to note that purpose is viewed by many authors as intention in the sense of a psychological cybernetic control system (Marken, 1990), managing behaviour in the sense of control ranging from extrinsic stimulations to intrinsic hints (Kerpelman, 2001), giving clear direction and guiding behaviour.

Attempting to define the notion of purpose, many authors consider it significant to emphasise that we are talking about a special ability that, like other forms of giftedness, has been equated with expert level achievement rather than being in accordance with prescribed norms (Bloom, 1985; Feldman, 1986); therefore, it has been defined as extraordinary or early achievement. In other words, many authors apply both of the characteristics that are typical features of the gifted to purpose as well, broadening the space of giftedness beyond the field of academic achievement to outstanding achievements in the fields of leadership and morality (Morgan \& Gardner, 2006). This is an additional argument in favour of the recent theories of giftedness that, when considering abilities, put stress on the importance of the way individuals use their abilities in constructive social purposes (Renzulli, 2002); this is important for the matter we are dealing with in the present paper, bearing in mind that it casts more light on the field of morality, which can be significant for the promotion of intercultural communications.

The question permeating the research refers to the following: to what extent in the case of the gifted in Serbia is purpose, i.e., the meaning of life, manifested?

Purpose, i.e., the meaning of life, grounded in the multiple intelligence theory and the purpose theory, as one aspect of moral giftedness, has been operationalised according to the dimensions adopted by Seana Moran. Consequently, sense, i.e., purpose, is considered through the issue of an awareness of what sense belongs to, through the value structure that is fundamental to meaning, and to what extent sense, i.e., purpose, has been built into intentions, activities and pro-social judgement. This covers the following questions:

- $\quad$ On what do gifted persons in Serbia place ethical focus, i.e., ethical sensibility?

- $\quad$ Can they be classified as moral experts due to their understanding of the moral social situation, and if so to what extent?

- To what extent do they understand the importance of living a moral life? 
Bearing in mind that the research searched for giftedness expressed in intrapersonal intelligence, i.e., for purpose as an inner moral compass, which has in numerous studies revealed itself as an indicator of intrapersonal intelligence, several basic findings point to the fact that this feature is present in a lower number of MENSA members in Serbia. Descriptive analysis of life meaning has shown that the life meaning of the subjects consists of the following values: personal development, a happy life, family, enjoying one's life, making a positive mark in life (doing something that lasts permanently for the benefit of the world in which the person lives), love in its broadest sense, selfrespect, dedication to work, health and friends.

A relatively low percentage of the gifted $(27.6 \%)$ stated values that open up possibilities for progress on both a personal level and the level of humanity. At this point, these have been classified as subjects having a pronounced sense of self-understanding, a significant purpose dimension. It should be noted here that along with the statement that the obtained number of subjects with the expressed features of moral giftedness is small, it should be borne in mind that we are dealing with an exceptionally selected sample, expected to offer the presence of this form of giftedness to a higher degree. When talking about a descriptive analysis of the field in which the subjects have achieved the most, they were classified into the following categories: science, art, personal education, interpersonal relations, education of others and emotional plan, which could be another indicator of purpose, i.e., grasping the meaning of life in the activities determining the accepted definition of purpose, the meaning of life. Furthermore, they are an indicator of the existence of not only pro-social thinking, but also engagement in the activities that can be in accordance with the operationalisation of purpose accepted in this paper. Finally, they are a confirmation of the assumption of the existence of a moral compass. In other words, the existence of this connection is a confirmation of the thesis on the existence of highly expressed intrapersonal intelligence in the case of every other subject, i.e., subjects with a self-organised life aim overcoming their own personality. However, this is not a finding that could seem satisfactory from the perspective of the theme we are dealing with, bearing in mind that what is generally expected from highly capable individuals is better understanding, early manifested mature interpersonal intelligence (the inner control system, the compass), as well as an orientation guiding gifted individuals, the ability to self-regulate their own engagement in culturally valuable activities, self-understanding as a critical ability leading to higher academic achievements and contributing to the society in which the individuals live, with a strongly expressed awareness of how they have found a way to integrate something personal and significant into 
their vision of tomorrow and the activities available to them. The individuality of these purposes is not such that we could conclude that the subjects would in greater number guide themselves more efficiently than others towards positive aspirations for others. It does not seem likely that if we compared these findings with the findings of the non-selected sample in the sense of high intellectual potentials, and if we checked the varying ethical giftedness in regard to age, we would gain the same findings that we obtained in this analysis. As a consequence, the conclusion might be reached that in the race for contemporary educational competences value orientation has been lost. Although the findings of the research outlined above are in a sense not connected with intercultural communication, it is important to reflect on the question as to how and to what extent it is possible to develop intercultural communication in the case of people who are absorbed only by the cognitive sphere and whose development of moral values is only implicitly involved. The world scene has already been threatened by communication dominated by individualism and this has been felt as a liability in the efforts insisting on group communication competencies. It seems that the stated outcomes - in spite of the fact that we are dealing with the results of explorative research on an intended sample including a highly selected population expected to have more expressed moral maturity and a value system with higher pro-social orientation - can be significant for the issue we are dealing with in the present paper. It would be good to keep these outcomes in the mind as we proceed through the text.

\section{Intercultural Communication Competencies}

The attitudes found in the literature regarding cultures, i.e., intercultural dialogues, are significant for reflection on intercultural communication. Many authors, including Avramović (2007) and Fayerstein, consider that culture shapes individual and collective lives in mysterious ways; it offers sense and meaning to life, shaping relations towards nature, man, the world, etc. Symbols are created and adopted according to culture, along with their explications and attitudes towards norms, enabling a person to interpret reality and project models of thinking and behaviour. Furthermore, the national form of culture is to be recognised in all of this. However, the national understanding of culture is not as simple as it may seem at first sight. Difficulties and dilemmas appear in any individual cultural shaping, due to the fact that the individual encouragement of personal development is inseparable from universal cultural meanings. All cultures have the same cultural phenomena (family, religious systems, artistic forms, etc.), but they are differently shaped and expressed. 
The inevitable link between a national and universal culture is not the only obstacle to those who have difficulties in accepting existing differences. Consequently, the differences within one culture (thinking styles, sub-cultures, etc.) are felt as a counterbalance to similarities within one culture (language, customs, beliefs, knowledge, etc., considered to be a continuum created for centuries). Many authors have expressed fear that these differences might lead to a distancing from national cultural identity acknowledgement. In spite of the fact that they are ready to see that in the admiration of one's own culture we fail to notice the great tension between what has been shaped by cultural tradition and what has been taken from other cultures, the question of openness of one culture towards others remains unanswered through the spread of cultural elements and the realisation of cultural encounters. The answer to the question has been sought in multiculturalism, i.e., interculturalism. Contemporary views on the turmoil in the cultures of small nations and their attitudes towards greater cultures suggest that they should now be called cultural pluralism, interculturalism, etc., thus only renaming the old phenomenon of cultural encounters and the spread of cultural values. Contacts between cultures are unstoppable. Educational programmes are only one of the channels of linking cultures. According to numerous authors in the field, while construing one's own I, an individual is free to choose how much he/she will take from the multicultural and how much from national culture while creating his/her spiritual portrait. Not even an escape to national culture can erase the clues and traces of the meanings and symbols of other nations gained in the family and school.

These issues have become a part of the discussions on curriculum design for various levels of educations. Questions regarding the limits of freedom of choice of cultural values of others have been discussed, as well as where the line is regarding multiculturalism, i.e., what is a reasonable extent to which another culture should participate in a national culture. Consensus has not yet been reached. According to many, the task of our cultural politics is, among other things, to make efforts in the preservation of national cultural identity. However, this aim is faced with the everyday spiritual obstructions of culture, i.e., the cultural dynamics in whose centre a clash has arisen between what culture has created and what it is becoming. According to the opinions of the advocates of this standpoint, the culture of the other is involved in this clash. In other words, no state politics has the mechanisms to draw a line between redundant and optimal multiculturalism in a national culture. Some other questions have also been raised: whether and why this is necessary or rational, and even whether it is possible. Numerous authors hold that given that every culture has historically built and shaped a language of meanings and a way of perceiving facts, giving 
meanings to the generations who in such a language and way of thinking can find answers to the secrets of existence, coexistence permeated with multiculturalism can also guide the spiritual power of an individual.

Some authors (Avramović, 2003) view this as a form of open culture, which in a way is both close to and far away from another culture. Searching for a new cultural perspective, foreign culture is, as a rule, a stimulus for new searches for similarities and differences in comparison to domestic culture. The literature offers the standpoint that the danger of eclecticism, as well as the threat to national cultural identity, can only be an excuse for incorrect political orientations, rather than real grounds for fear. State preservation of national cultures or political protection of cultural individuality is not something directly related to multiculturalism. On the contrary, the fictive fear of loss of cultural identity can, on certain levels of individual development, result in an escape into tradition and the creation of an imaginary structure of cultural awareness (Avramović, 2003).

It seems that in the culture of Serbia the relation of personal and group identity towards multiculturalism differs depending on the region, the historical past, i.e., the historical and diachronic determination of personality and, in the view of Kelly and the constructivists, only in regard to the approach here and now.

In the literature one can find Kelly's standpoints (Stojnov, 2003) that a personality can be better understood if it is viewed in the perspective of ages, rather than in the sparkle of passing moments. This moves us further towards those authors who hold that the relation between multicultural and national can be considered as two poles of culture, as seen by Avramovic. Consequently, the issues of their relation have always been relevant, but they have been explicated in various ways. So, it seems that we could accept that the current issue will always be a matter of choice between the cultural politics of a state, an individual and a creative group. What is interesting for the present paper is the perspective of education as a factor of the multicultural communication of an individual, his/her determination in relation to the cultural heritage of his/her own people and other nations.

Alternative constructivism (Kelly's psychology of personal constructs) could be a suitable theoretical framework for the theme of education as a factor of intercultural communications, advocating a historical and diachronic understanding of personality as a never-ending flow, constant change, carrying from the gnoseological perspective a certain amount of contradiction, bearing in mind that it is at the same time a form of rationalism, considering that people construe through reasonable categories, as well as a type of empiricism, since 
each construction, no matter how rational it might be, has to be validated in behaviour. The validation is not aimed at confirming whether a construction is truthful or not, but whether it is useful, classifying the theory of personal constructs into the group of pragmatic ones, directing the cultural determination of a person towards diachronic understanding - rather than understanding the here and now.

The ontological status of Kelly's theory of personal constructs is determined by monism, i.e., understanding that the ultimate factor of the world is the one and only. What the world is made of can be construed in a variety of ways, making the position pluralistic. His efforts to determine the psychology of personal constructs ontologically shows an inclination to confront it with realism, i.e., to express disbelief of a great number of his advocates in the existence of one external reality beyond the knowledge and thought of men. Namely, people themselves construe their own versions of reality and behave as if they were "real«, with each person construing his/her own alternative constructions. We can conclude that in his theory Kelly has postulated an outer reality, i.e., culture. From the perspective of the cultural determination of a person we would say that culture is one phenomenon, something that is going on and that we understand, thus anticipating it. Therefore, the psychology of personal constructs is interested in anticipations, i.e., constructs of people, not in material objects existing independently of their experience. Knowledge of culture is not limited by the inherent qualities of culture itself (European or national), and it is not beyond the act of knowing itself, but it is limited by the imaginative capacity of the human mind; thus the limitations of the reaches of all knowledge up to now are implicitly emphasised, since everything is subjected to replacement and revision. Kelly did not deny the existence of the world beyond the experience of people, but he, according to Stojnov, just like Niche, considered that such a world existed in a completely undetermined way. According to Kelly, the world cannot be known beyond the limitations of people's experience, outside a referent frame that serves to enable people know the world. And all of this, as an attempt to provide argumentation for the frame of the thesis permeating the text, refers to the issue of education as an intercultural factor, with the culture striving to become Europeanised itself through the Europeanisation of education. It also refers to the extent to which the pluralism of the cultural European space is involved in national culture through education, leading to a pluralism that today increasingly turns to issues of values disputing the legitimacy of tradition. At first sight, distant elements like culture - or educational content in the broadest sense in contemporary views on personality, touched through a brief outline of Kelly's alternative constructivism in order to create a context for getting closer 
to pluralism as a contemporary feature of European didactics - have found their place in the chain of elements closing the circle of postmodern didactics. In didactics, postmodern thinking emphasises a call for adjustment to a pluralism of life styles, i.e., cognitive functioning, meaning a need for didactics to search for individuality rather than identity. Beyond all of this we could consider the aspirations towards interculturalism as a pluralistic educational context. Numerous authors find the argumentation for this in one of the accents of postmodernism in pedagogy, even in didactics. This is derived from the Berlin pedagogic circle, the so-called reflexive relation of theory on education towards education itself - practice. The new definition of this relation (between theory and practice) as a significant feature has a standpoint according to which educational science is no longer a science of action (it does not prescribe, it does not give suggestions as to what should be done). Another angle is offered by the Hamburg pedagogue H. Pojkert and deals with the normative consequences of pedagogical interaction. Within this framework, pedagogy is searching for ways of more comprehensive self-perception and morally-reflected self-guidance and self-changes in order to ensure the freedom of a person's actions. All of this, under the influence of contemporary philosophical discussions, has made it possible for pedagogy to abandon the scene of so-called »closed didactics « and to embrace »open didactics«, formed according to Habermas's model of interests, within the phenomenological-anthropological, even holistic, tradition of thought that is open towards unstable forms of practise, ideas and cases, giving more freedom and competencies to the teacher and emphasising the individuality of the student and his/her capability for social action.

It seems that theoretical pluralism and anarchistic epistemology can well serve as grounds for understanding the needs for the diachronic cultural determination of a personality in European integration. As a consequence, open emancipatory pedagogy is turned to the student, with phenomenological approaches making it difficult for general structure and pedagogical elements to function, bearing in mind that, turned to the student, they have a personal note, practical-interactive, social-emancipatory, etc. It is considered that the essence of pedagogy lies in striving for creating the points enabling a student to guide »co-determined « learning, self-responsible and co-responsible action. Literature points to the fact that emancipatory pedagogy anticipates the tendency towards the relativisation of content, i.e., the open curriculum underlined by clear tones of anarchistic epistemology. Kelly talks about and the avoidance of dogmatism of method and theory, dogmatism of education of the rational term of rationalistic method, as well as thinking principles subjected to change. Based on Popper's philosophical orientation, as well as Feyerabend's 
attitude, beyond all of these standpoints it can be recognised that there are ways to create different paradigms, bans, pre-formulations, etc., in different cultures. This is the point where we could get closer to the current issue for which the matter of the emphasis on context seems to be very important. Context awareness, i.e., education as a factor of intercultural communication, anticipates the world in which young people live in a time of the Internet and other forms of telecommunications that know no limits, barriers, bans. Changes, permeations, are inevitable and unstoppable. Furthermore, as has been emphasised by numerous authors, these changes should be viewed from an enriching perspective, i.e., from the perspective of possibilities to form competences through education that contribute to the creation of competencies for intercultural communication.

The understanding of competencies in the text thus far has, as a construct, its essence in the complexity of individual-social relations, based on various abilities and characteristics conditioned by numerous factors and manifested in various levels of individual and social human functioning. In a less complicated manner, competency could be determined as a capacity for the successful achievement of an individual in the social world. This capacity is based on a set of dispositional features, verbally and socially construed meanings, thus representing a whole that is something more than their simple sum. The quality and extent to which the aforementioned features will be developed are conditioned by the dynamic actions of individual-social interactions and their feedback effects. Competency of the individual is therefore considered to be not only an individual feature but an interpersonal and social feature. Capacity for individual competence, as it is nowadays considered by numerous authors, develops throughout one's life, and does not refer solely to personal advancement and happiness. Thus it is seen as a relational category, gaining its full meaning, form and measure of successfulness in interaction with other people and the level of quality of their progress.

The previous view on the construct of competency is indisputably based on cognitive processes, bearing in mind that these processes enable the understanding of social relations, phenomena, changes, a familiarisation with one's own roles and the roles of others in the family, professional and community life: to judge what should be done in each of these roles if one is to achieve success. Decision making ability, problem solving ability, as well as the planning of future activities are the cornerstone of the successful individual and social behaviour of an individual. This is also a basis for an ability to self-develop, known as the ability of self-competence (along with social competence, the second basic feature of competence). Relying on this, it could be said that the most 
important features thought to be necessary if an individual is to achieve in both individual and social life, and which can also be considered to be the criteria for the guidance of his/her competency development, are the following: autonomy, tolerance, participation, openness, flexibility.

The above outlined desirable communicative and self-reflexive features are considered to be in close relation and mutually dependant, influencing a person as a whole system and his/her interaction with the setting. On the other hand, they are considered to be indicators of success of the development of interaction and total social behaviour. As guidelines and criteria for competency development they are build into concepts of both of the aforementioned aspects of competence - self-competence and social competence.

Self-competence would thus include both aspects, individual and social, since development, understood as a life-long process, takes place in the process of socialisation - as the development of both the individual and social being. The social side in this conception does not have a limiting aspect in relation to individual, personal progress, to aspirations towards the freedom of individual advancement. Or, to put it differently, balance is expected in relations with others, organised so that it does not limit either side in the relation. The concept of competence in itself carries personal characteristics (thinking, judgment, evaluation, emotional expression, etc.), but, on the other hand, its "products«, expressed in construed meanings and a readiness to react based upon them, have deep social meaning and origin. Therefore, dynamic interaction is considered to be two sides of one conditionally divided process. At the same time, the view of reality, although determined by numerous exterior circumstances, is comprehended and experienced in personal way, subjectively and individually by every individual. Behind all of this, the phenomenon of competence could easily be classified under those competences that are in a manifold way determined by subjective meanings, evaluation, the orientation and experience of the individual, serving as a basis for the process of the individual's self-competence development.

It seems that a better understanding of self-competence cannot be achieved without Jung's individuation concept, according to which a man is a self-understanding being, striving for autonomy and personal efficacy, selfcompetence. We point to the following as frequently highlighted features of self-competence:

- $\quad$ readiness to accept new experiences and ideas, open-mindedness and cognitive flexibility;

- $\quad$ independence and autonomy in relation to traditional sources of influence; 
- $\quad$ an explicit sense of personal efficacy in individual and social settings;

- $\quad$ being informed and ready to participate.

These complex features, formed in the period of individualisation, are a great challenge, not only for the individual but also for society, as well as for education. From the perspective of self-competence they help the individual to understand it as an ability to organise him/herself and his/her own everyday life, according to his/her own view but with respect to those with whom everyday life is shared. Numerous authors hold that the key competences of education for intercultural communication are the following:

- $\quad$ Self-understanding skills:

- an ability for dialogue and a readiness for communication (intercultural orientation);

- (self-)reflection ability (articulates personal motives and interests, determination of one's own viewpoints, along with an ability for self-criticism and an accurate perception of one's own learning potentials and achievements);

- value orientation (the guideline of life orientation is humanistic, and ethical principles are rightfulness, responsibility, etc);

- ability for conflict solving (search for reasonable and acceptable compromises, non-violent conflict resolutions, etc.).

- $\quad$ Cooperation skills:

- readiness for international cooperation;

- team work skill;

- community orientation;

- networked learning (an ability to consider and get closer to various sources of information, experience, in order to develop a network of informal contacts and offers for help and cooperation).

- Efficiency skills:

- decision making skill (in various complex and risk situations);

- action competence;

- participation competence (with an accent on responsibility).

- $\quad$ Self-organisation skills:

- guidance of one's own learning process (metacognitive features development); 
- evaluation competence (self-evaluative competence);

- life-long learning (learning is seen as life quality enrichment).

- Comprehension skills:

- an ability to view from various angles (different dimensions and meanings);

- constructivist treatment with multiple approaches (making connections between various methods, ways of looking and competences when problem solving - pluralistic thinking);

- global perspective (local experiences and ways of their solution are connected to possible actions on a global level).

\section{Conclusion}

Communication and self-reflective skills are nowadays considered to be key competences of intercultural dialogue and integration in contemporary European and broader frames. One of the important questions contemporary pedagogues ask themselves is how they see the possible models of efficient education for a contemporary society characterised by rapid changes and currents, and for a Europe that is making huge strides towards ever closer integration, thus building specific human intercultural relations. In such an educational concept, nowadays called »a concept of education for action competence», the ability and readiness of an individual to follow and guide changes, as well as the readiness of an individual to solve problems of personal and social reality, anticipating, among other things, competence for intercultural communication, emphasis is placed on education that will contribute to the development of a capacity for constructive determination towards the development of an ability to develop a suitable and acceptable relation towards differences in an intensified sensitivity for the interests of others, differences that do not have to be a cause of conflict. Many European educational models emphasise the importance of critical judgement as a necessary precondition for conflict resolution, the autonomous behaviour of an individual in the contemporary world, as well as an omen of the development of critical, autonomous individuals and »selfdirected « education. That which is expected of education is to encourage the development of such "reflexive « individuals, thus enabling the influence of a citizen on the process of reaching and developing democracy. For education in Serbia, which is attempting to catch up with European tendencies and to make it possible for society to entered the processes of a »learning society«, communicative and self-reflexive skills are also important. As already pointed out, 
these skills are considered to be the key competencies of intercultural dialogue. Therefore, it would be significant to study what the competence for intercultural communication really is and to go a step further in consideration of the role of education in the provision of the aforementioned intercultural dialogue competences. This would certainly be a guideline for practical actions to be undertaken to make curricula more modern and to pay attention to other aspects of educational care.

According to the standpoints offered in the above text, what should be of great importance is a system of values that, as has already been mentioned, represents the orienting point, the purpose, the meaning in life, guiding and directing life while creating and guiding the aforementioned competences, or vice-versa.

\section{Acknowledgements}

The article presents results of the project 179036 / 2011-2014 and it carried out with the financial support of the Serbian Ministry of Science.

\section{References}

Avramović, Z. (2003). Čiji je književnik i njegovo delo. S. Karlovci i N. Sad: Izdavačka knjižarnica Z.

Stojanovića.

Avramović, Z. (2003). Država i obrazovanje. Belgrade: Institut za pedagoška istraživanja.

Babić, J. (2005). Moral i naše vreme. Belgrade: Službeni glasnik.

Bauman, Z.. Postmodern Enthich. Retrieved from www.concord/inti/papers/.

Burbules, C. N. (2000). Globalization and Education. New York: Routledge.

Damon, W. (2008). The path to purpose: Helping our children find their calling in life. New York: Free Press.

Damon, W., Menon, J., \& Bronk, K. C. (2003). The development of purpose during adolescence. Applied Developmental Science, 7(3), 119-128.

Gardner, H. (1993). Creating minds. New York: Basic Books.

Gardner, H. (1999). Intelligence reframed: Multiple intelligences for the 21st century. New York: Basic Books.

Gestdottir, S., \& Lerner, R. M. (2007). Intentional self-regulation and positive youth development in early adolescence: Findings from the 4-H study of positive youth development. Developmental Psychology, 43(2), 508-521.

Gojkov, G. (2005). Didaktika i postmoderna. Vršac: VŠV.

Gojkov, G. (2006). Metateorijske koncepcije pedagoške metodologije. Vršac: VŠV.

Gojkov, G. (2008). Didaktika darovitih [Didactics of the Gifted]. Vršac: Visoka škola strukovnih studija za obrazovanje vaspitača »Mihailo Palov«.

Gojkov, G. (2008). Metodološki problemi istraživanja darovitosti [Methodological Problems in 
Giftedness Research]. Vršac: Visoka škola strukovnih studija za obrazovanje vaspitača »Mihailo Palov«.

Gojkov, G. (2009). Didaktika metakognicije. Vršac: Visoka škola strukovnih studija za obrazovanje vaspitača »Mihailo Palov«.

Gojkov, G., \& Stojanović, A. (2009). Nacionalni identitet i susreti kultura iz ugla darovitih [National identity and cultural encounter from the perspective of the gifted]. Novi Sad: Filozofski fakultet. Grant, H., \& Dweck, C. S. (2003). Clarifying achievement goals and their impact. Journal of Personality and Social Psychology, 85(3), 541-553.

Gudjons, H. (1998). Pedagogija. Zagreb: Educa.

Jung, K. G. (2000). O razvoju ličnosti. Belgrade: SL. list SRJ.

Kelly, G.A. (1955). The Psychology of Personal Constructs. New York: Norton.

Kerpelman, J. L. (2001). Identity control theory, exploration, and choice: A commentary on Schwart's The evolution of Eriksonian and Neo-Eriksonian identity theory and research. Identity, 1(1), 81-86.

Kron, F. W. (1996). Grundwissenn Pedagogik. Munchen, Basel: E.R., Reinhardt.

Lapsley, D. K., \& Narvaez, D. (Eds.) (2004). Moral development, self, and identity. Mahwah, NJ: Erlbaum.

Lencen, D. (1992). Reflexive Ercie am Ausgang des postmodernen Jahrzenhts. In 29.Beiheft der Z.f.Pa.

Lerner, R. M., Lerner, J. V., Almerigi, J., \& Theokas, C. (2005). Positive youth development, participation in community youth development programs, and community contributions of fifth grade adolescents: Findings from the first wave of the 4-H Study of Positive Youth Development. Journal of Early Adolescence, 25(1), 17-71.

Locke, E. A., \& Latham, G. P. (1990). A theory of goal setting and task performance. Englewood Cliffs, NJ: Prentice Hall.

Marken, R. S. (1990). A science of purpose. American Behavioral Scientist, 34(1), 6-13.

Matsuba, M. K., \& Walker, L. J. (2005). Young adult moral exemplars: The making of self through stories. Journal of Research on Adolescence, 15(3), 275-297.

Moran, S. (2009). Why MI? In J. Chen, S. Moran, \& H. Gardner (Eds.), Multiple intelligences around the world (pp. 365-373). San Francisco, CA: Jossey-Bass.

Moran, S., \& Gardner, H. (2006). Extraordinary cognitive development. In W. Damon (Series Ed.), D. Kuhn, \& R. Siegler (Vol. Eds.), Handbook of child psychology (6th ed., Vol. 2, pp. 905 - 949). New York: Wiley.

Moran, S., \& Gardner, H. (2007). Hill, skill and will: A multiple intelligences perspective. In L. Meltzer (Ed.), Understanding executive function: Implications and opportunities for the classroom (pp. 19-38). New York: Guilford Press.

Mušanović,M. (1996). Postmoderne epistemologije pedagogije. Pedagogija i hrvatsko školstvo. Zagreb. Nurmi, J-E. (1991). How do adolescents see their future? A review of the development of future orientation and planning. Developmental Review, 11, 1-59.

Renzulli, J. S. (2002). Expanding the conception of giftedness to include co-cognitive traits to 
promote social capital. Phi Delta Kappan, 84(1), 33-58.

Stojanović, A. (2008). Uticaj multikulturalnog vaspitanja na vrednosne orijentacije učenika [The influence of multicultural education on the value orientation of students]. Pedagogijska istraživanja, $5(2)$.

Stojnov, D. (2003). Psihologija ličnih konstrukata-uvod u teoriju i terapiju. Beograd: Zepter, Bookworld.

Zimmerman, B. J. (2008). Goal setting: A key proactive source of academic self-regulation. In D. H. Schunk \& B. J. Zimmerman (Eds.), Motivation and self-regulated learning: Theory, research and applications (pp. 267-295). Mahwah, NJ: Erlbaum.

\section{Biographical note}

GrozDANKA Gojkov, born in 1948, has a PhD degree in didactics at the University in Novi Sad. She teaches at the Teacher Training Faculty, Belgrade, teaching department in Vrsac; at the Preschool Teacher Training College "Mihailo Palov« in Vrsac; and at Primary School Teachers Faculty in Uzice. She is also a director of the Preschool Teacher College in Vrsac and an editor of the publishing activities at the same institution. She is a member of many national and international organizations (e. g. ECHA - European Council for High Ability; Central European Academy of Science; Serbian Academy of Education in Belgrade, etc.) and a visiting professor. Fields of interests and research: epistemological grounds of pedagogic research; giftedness (the factors of transferring potentials into achievements; pluralism in teaching from the angle of the gifted); didactics (strategies of meta-cognition encouragement; docimology, meta-theoretical approaches to didactics). 